Published in final edited form as:

Bioconjug Chem. 2004 ; 15(6): 1441-1446.

\title{
Preparation and Properties of $99 \mathrm{mTc}(\mathrm{CO})_{3}{ }^{+-}$Labeled $\mathrm{N}, \mathrm{N}$-Bis(2- pyridylmethyl)-4-aminobutyric Acid
}

\author{
Guozheng Liu*, Shuping Dou, Jiang He, Jean-Luc Vanderheyden, Mary Rusckowski, and \\ Donald J. Hnatowich \\ Department of Radiology, Division of Nuclear Medicine, University of Massachusetts Medical \\ School, Worcester, Massachusetts 01655.
}

\section{Abstract}

Labeling biomolecules with ${ }^{99 \mathrm{~m}} \mathrm{Tc}(\mathrm{CO})_{3}{ }^{+}\left({ }^{99 \mathrm{~m}} \mathrm{Tc}\right.$ tricarbonyl) is attracting increasing attention. Although histidine is often considered an ideal bifunctional chelator for ${ }^{99 \mathrm{~m}} \mathrm{Tc}$ ( or ${ }^{188} \mathrm{Re}$ ) tricarbonyl, the family of dipicolylamine carboxylate chelators may be a useful alternative because of the expected ease of synthesis and because the structure provides a pendent carboxylate for potential conjugation to biomolecules. The dipicolylamine chelator $N, N$-bis(2-pyridylmethyl)-4-aminobutyric acid (BPABA) was synthesized using 4-aminobutyric acid in place of glycine or aminopropionic acid in the literature, to avoid possible involvement of the carboxylate in the complex formation process by forming five- or six-membered chelation rings. Using a commercial tricarbonyl kit (Mallinckrodt), the complex formation properties of both BPABA and commercial histidine with ${ }^{99 \mathrm{~m}} \mathrm{Tc}$ tricarbonyl were investigated, and the in vitro complex stabilities in saline and in serum were compared. Stability in vivo was also examined following i.v. administration to normal mice. BPABA was synthesized simply and quantitatively by reacting picolyl chloride with aminobutyric acid in one step. On RP HPLC, the product eluted essentially in one peak and the structure was confirmed by ESI-MS. After labeling, both BPABA and histidine were shown by RP HPLC to form tricarbonyl complexes. In both cases, after incubation at $100{ }^{\circ} \mathrm{C}$ for $20 \mathrm{~min}$, only one predominant peak of ${ }^{99 \mathrm{~m}} \mathrm{Tc}(\mathrm{CO})_{3}{ }^{+}-$ histidine or ${ }^{99 \mathrm{~m}} \mathrm{Tc}(\mathrm{CO}) 3_{3}{ }^{+}$-BPABA was apparent, and both complexes were stable at room temperature in saline for at least $24 \mathrm{~h}$. After incubation for $24 \mathrm{~h}$ in $37^{\circ} \mathrm{C}$ serum, by SE HPLC, 20\% of the ${ }^{99 \mathrm{~m}} \mathrm{Tc}(\mathrm{CO})_{3}{ }^{+}$-histidine was bound to serum protein compared to less than $10 \%$ for ${ }^{99 \mathrm{~m}} \mathrm{Tc}$ $(\mathrm{CO})_{3}{ }^{+}$-BPABA. A 5000 molar excess of histidine at $100^{\circ} \mathrm{C}$ for $6 \mathrm{~h}$ was unable to dissociate ${ }^{99 \mathrm{~m}} \mathrm{Tc}$ $(\mathrm{CO})_{3}{ }^{+}-\mathrm{BPABA}$. By contrast, BPABA easily dissociated ${ }^{99 \mathrm{~m}} \mathrm{Tc}(\mathrm{CO})_{3}{ }^{+}$-histidine under the same conditions. Both complexes were stable in vivo in mice, and ${ }^{99 \mathrm{~m}} \mathrm{Tc}(\mathrm{CO})_{3}{ }^{+}-\mathrm{BPABA}$ showed rapid and specific hepatobiliary clearance while ${ }^{99 \mathrm{~m}} \mathrm{Tc}(\mathrm{CO})_{3}{ }^{+}$-histidine was cleared through the kidneys. In conclusion, BPABA was easily synthesized and was shown to possess properties comparable to histidine for labeling of biomolecules with ${ }^{99 \mathrm{~m}} \mathrm{Tc}$ tricarbonyl. However, it was found that the chelator concentration required for quantitative ${ }^{99 \mathrm{~m}} \mathrm{Tc}$ tricarbonyl labeling with both BPABA and histidine were 2 orders higher than that required with more conventional labeling using $\mathrm{MAG}_{3}$. Finally, the complex $99 \mathrm{mTc}(\mathrm{CO})_{3}{ }^{+}-$BPABA itself was found to clear exclusively via the hepatobiliary pathway and may have value as a potential hepatobiliary imaging agent.

\section{INTRODUCTION}

We have been investigating tumor imaging by pretargeting with antibodies conjugated with phosphodiamidate morpholino oligomers (MORFs) along with ${ }^{99 \mathrm{~m}}$ Tc-radio-labeled complementary MORFs as effector using $\mathrm{MAG}_{3}$ as chelator (1-4). Our overall objective is to

\footnotetext{
* To whom correspondence should be addressed: Donald J. Hnatowich. Ph.D., Department of Radiology, Division of Nuclear Medicine, University of Massachusetts Medical School, 55 Lake Ave. North, Worcester, MA 01655-0243. Phone: (508) 856-4256. Fax: (508) 856-4572. E-mail: Donald.hnatowich@ umassmed.edu..
} 
perform ${ }^{188}$ Re radiotherapy using this MORF pretargeting approach. While $\mathrm{MAG}_{3}$ performs well as a chelator for $99 \mathrm{mTc}$, it falls short of ideal for the chelation of ${ }^{188} \mathrm{Re}$. Preliminary studies showed that, when using $\mathrm{MAG}_{3}$ as a chelator for ${ }^{188} \mathrm{Re}$ in the labeling of MORF, oxidization to ${ }^{188} \mathrm{ReO}_{4}{ }^{-}$during preparation was excessive (5). Since more suitable chelators for ${ }^{188} \mathrm{Re}$ are therefore still needed, the ${ }^{188} \mathrm{Re}$-tricarbonyl core was investigated as an alternative labeling strategy because of the predicted kinetic inertness of these complexes (6-8). Initially, the ${ }^{188}$ Re tricarbonyl labeling was achieved with Hynic-MORF (9). Evaluation showed improved stability of the label to oxidation but with kidney levels high enough to be problematic with ${ }^{188} \operatorname{Re}$ (or ${ }^{99 \mathrm{~m}} \mathrm{Tc}$ ). We suspected that the tricarbonyl complexes $(10,11)$ was binding to robust groups such as imidazole in kidney tissue proteins possibly through interaction of the open position of the tricarbonyl complex of the bidentate Hynic chelator.

Numerous ligands have now been recommended as chelators for labeling biomolecules with technetium or rhenium tricarbonyl cores, and it now seems clear that bidentate chelators are not ideal because of the remaining open position $(10,11)$. Of the tridentates considered, those containing the basic formula of [aromatic N-heterocycle]-[amine]-[carboxylate] have received the most attention $(8,10-14)$, although the tridentates [aromatic $\mathrm{N}$-heterocycle][amine]-[thiol] (15) and [thioether]-[thioether]-[carboxylate] (16) have also been tested. Examples of rhenium tridentate tricarbonyl complexes are shown in Figure 1. Recently, when $\mathrm{N}, \mathrm{N}$-dipicolyl-glycine or $\mathrm{N}, \mathrm{N}$-di(imidazolylmethyl)glycine was allowed to react with Re $(\mathrm{CO})_{3}{ }^{+}$, the complex with the two aromatic $\mathrm{N}$-hetercyclic nitrogens and the amine in coordination was obtained leaving the carboxylate free (17). This suggested that tridentates with the formula of [aromatic N-heterocycle]-[amine]-[aromatic N-heterocycle] might be preferable for technetium or rhenium tricarbonyl labeling over [aromatic N-heterocycle][amine]-[carboxylate].

Lately we have become particularly interested in tridentates of $N, N$-dipicolyl- $\omega$-amino acids. Besides providing the [aromatic N-heterocycle]-[amine]-[aromatic N-heterocycle] chelation site, these molecules have a pendent carboxylate group suitable for conjugation to the amines on biomolecules. They can be synthesized in one step simply by reacting picolyl chloride with the corresponding $\omega$-amino acid (17).

We report herein on the labeling with ${ }^{99 \mathrm{~m}} \mathrm{Tc}(\mathrm{CO})_{3}{ }^{+}$of a new dipicolylamino acid and the properties of the complex. While our ultimate goal is to develop a chelation strategy for ${ }^{188} \mathrm{Re}$ $(\mathrm{CO})_{3}{ }^{+}$, in this investigation ${ }^{99 \mathrm{~m}} \mathrm{Tc}(\mathrm{CO})_{3}{ }^{+}$was used instead because of the ready availability of ${ }^{99 \mathrm{~m}} \mathrm{Tc}$ and its tricarbonyl kit with a recognition of the structural similarities between rhenium and technetium.

\section{MATERIALS AND METHODS}

Bis(2-pyridylmethyl)-4-aminobutyric acid (BPABA), also called dipicolylaminobutyric acid, was synthesized in house while histidine was purchased from Aldrich (St. Louis, MO). The MS analysis was performed by the UMMS Proteomics and Mass Spectometry Facility. The Isolink kits for synthesizing ${ }^{99 \mathrm{~m}} \mathrm{Tc}(\mathrm{CO})_{3}{ }^{+}$were gifts from Mallinckrodt Medical (St Louis, $\mathrm{MO}$ ). Each lyophilized kit contained $8.5 \mathrm{mg}$ of sodium tartrate, $2.85 \mathrm{mg}$ of $\mathrm{Na}_{2} \mathrm{~B}_{4} \mathrm{O}_{7} \cdot 10 \mathrm{H}_{2} \mathrm{O}$, $7.15 \mathrm{mg}$ of sodium carbonate, and $4.5 \mathrm{mg}$ of sodium boranocarbonate. $\mathrm{The}^{99} \mathrm{~m}^{9} \mathrm{TcO}_{4}{ }^{-}$was eluted from a ${ }^{99} \mathrm{Mo}-{ }^{99} \mathrm{~m} \mathrm{Tc}$ generator (Bristol-Myers Squibb MedicalImaging, Inc., North Billerica, MA). All other chemicals were reagent grade and were used without purification.

\section{Synthesis of Bis(2-pyridylmethyl)-4-aminobutyric Acid (BPABA)}

The reaction was achieved essentially according to a reported procedure (17) with a modification in separation method. The 2-chloromethylpyridine hydrochloride (33.7 g, 196 $\mathrm{mmol})$ and 4-aminobutyric acid $(8.3 \mathrm{~g}, 80 \mathrm{mmol})$ were dissolved in $100 \mathrm{~mL}$ of water, and the 
$\mathrm{pH}$ was adjusted to 10 and maintained in the range of $8-10$ for $4 \mathrm{~d}$ by adding $5 \mathrm{M} \mathrm{NaOH}$ at intervals (total $\sim 18 \mathrm{~g}, 450 \mathrm{mmol})$. The black reaction mixture was washed with $\mathrm{CHCl}_{3}(70 \mathrm{~mL}$ $\times 4$ ), followed by $\mathrm{pH}$ adjustment to 8 and concentration of the aqueous phase via evaporation. Toward the end of the evaporation, concentrated $\mathrm{HCl}$ was added to facilitate removal of as much $\mathrm{NaCl}$ as possible. The product was characterized by ESI-MS and HPLC.

\section{HPLC Analysis}

Reverse phase HPLC (RP HPLC) with an YMC-Pack C-18 column (system 1) was used for separation and analysis during synthesis of BPABA, while a Vydac C-18 column (system 2) was used for analysis during the ${ }^{99 \mathrm{~m}} \mathrm{Tc}$ tricarbonyl labeling. Size exclusion HPLC (SE HPLC) was also used for in vitro and in vivo stability investigations of the ${ }^{99 \mathrm{~m}} \mathrm{Tc}$ tricarbonyl complexes (system 3).

System 1-Semipreparative YMC-Pack C-18 column $(250 \times 10 \mathrm{~mm}, 5 \mu \mathrm{m}, 323 \AA) ; 10 \mathrm{mM}$ $\mathrm{HCl}$ as solvent $\mathrm{A}$ and acetonitrile as solvent $\mathrm{B}$; flow $2.0 \mathrm{~mL} / \mathrm{min}$. Gradient table: $0-15 \mathrm{~min}$, 90\% A; 15-20 min, 90-70\% A; 20-23 $\min , 70-90 \%$ A, and 23-35 min, 90\% A.

System 2-The Vydac C-18 column $(5 \mu \mathrm{m}, 250 \times 4.6 \mathrm{~mm})$; 0.05 M TEAP (triethylamine phosphate, $\mathrm{pH}$ 2.0) as solvent A and methanol as solvent B; $1.0 \mathrm{~mL} / \mathrm{min}$. Gradient table: $1-3$ min, $100 \%$ A; 3-6 min, $100 \%-75 \%$ A; 6-9 min, $75 \%-66 \%$ A; 9-20 min, 66\%-0\% A; 20-27 min, 0\% A; 27-40 min, 0\%-100\% A; 40-50 min, 100\% A.

System 3-The Superose-12 size-exclusion column; 0.10 M pH 7.2 phosphate buffer; isocratic flow $0.6 \mathrm{~mL} / \mathrm{min}$.

\section{Formation of ${ }^{99 \mathrm{~m}} \mathrm{Tc}(\mathrm{CO})_{3}+$ Complexes}

The ${ }^{99 \mathrm{~m}} \mathrm{Tc}(\mathrm{CO})_{3}{ }^{+}$core was prepared fresh daily by introducing $1 \mathrm{~mL}$ of ${ }^{99} \mathrm{mcO}_{4}{ }^{-}$saline solution into a kit and heating in boiling water. An incubation time of 20 min was routinely used. After neutralization with $120 \mu \mathrm{L}$ of $1 \mathrm{~N} \mathrm{HCl}$, an equal volume of aliquot was added to a vial containing either $1 \mathrm{mM}$ BPABA or $1 \mathrm{mM}$ histidine of $\mathrm{pH} 7.0$ and heated in a boiling water bath normally for $20 \mathrm{~min}$. Both the labeled compounds of ${ }^{99 \mathrm{~m}} \mathrm{Tc}(\mathrm{CO})_{3}{ }^{+}-\mathrm{BPABA}$ or ${ }^{99 \mathrm{~m}} \mathrm{Tc}$ $(\mathrm{CO})_{3}{ }^{+}$-histidine were characterized by RP HPLC (system 2 ) and SE HPLC.

\section{In Vitro Stability of ${ }^{99 \mathrm{~m}} \mathrm{Tc}(\mathrm{CO}) 3_{3}{ }^{+}$-Labeled BPABA and Histidine}

The stabilities of both complexes were tested by diluting the labeled solution 100 fold in saline or human serum, incubating at $37^{\circ} \mathrm{C}$, and analyzing at intervals using SE HPLC.

The affinity of ${ }^{99 \mathrm{~m}} \mathrm{Tc}(\mathrm{CO})_{3}{ }^{+}$for BPABA relative to histidine was also measured by mixing ${ }^{99 \mathrm{~m}} \mathrm{Tc}(\mathrm{CO})_{3}{ }^{+}-\mathrm{BPABA}$ in $100 \mathrm{mM}$ histidine at a molar ratio of BPABA to histidine of 1:5000 and incubating either at $37^{\circ} \mathrm{C}$ for $24 \mathrm{~h}$ or in a boiling water bath $6 \mathrm{~h}$. The identical procedure was also performed starting with ${ }^{99} \mathrm{~m} \mathrm{Tc}(\mathrm{CO})_{3}{ }^{+}$-histidine in $100 \mathrm{mM}$ BPABA.

\section{In Vivo Stability and Biodistribution of ${ }^{99 \mathrm{~m} T c}$ Tricarbonyl-Labeled BPABA}

A group of four normal CD-1 mice (35-45 g) were each injected with $70 \mu \mathrm{Ci}$ of ${ }^{99 \mathrm{~m}} \mathrm{Tc}$ $(\mathrm{CO})_{3}{ }^{+}$-BPABA or ${ }^{99 \mathrm{~m}} \mathrm{Tc}(\mathrm{CO})_{3}{ }^{+}$-histidine via a tail vein. After $35 \mathrm{~min}$, the mice were sacrificed under halothane anesthesia. Selected organs were harvested and rinsed, and their radioactivity was measured in a Cobra II auto-gamma counter (Packard, Downers Grove, IL). To provide an estimate of in vivo stability, plasma, urine, and an extract from small intestine contents were analyzed by SE HPLC. Plasma was obtained by adding $0.5 \mathrm{~mL}$ of blood from each mouse into a tube containing $0.068 \mathrm{~mL}$ of $7.5 \% \mathrm{~K}_{3}$ EDTA followed by centrifugation at 
$650-700 \mathrm{~g}$ for $10 \mathrm{~min}$. The small intestine extract was obtained by washing with $4 \mathrm{~mL}$ of water and centrifuging the wash at $2500 \mathrm{~g}$ for $20 \mathrm{~min}$.

\section{RESULTS}

\section{Characterization of BPABA}

Analysis by RP HPLC (System 1) reveals one major peak at 7.8 min with over $90 \%$ of peak area and a small peak at 8.7 min, presumably due to $\left(\mathrm{PyCH}_{2}\right)_{2} \mathrm{~N}\left(\mathrm{CH}_{2}\right)_{3} \mathrm{COOH}$ and $\left(\mathrm{PyCH}_{2}\right)_{3} \mathrm{~N}^{+}\left(\mathrm{CH}_{2}\right)_{3}-\mathrm{COOH}$. The broad peak at $29 \mathrm{~min}$ is due to the solvent.

The ESI-MS analysis of BPABA shows a product peak attributed to $\left[\left(\mathrm{PyCH}_{2}\right)_{2} \mathrm{NH}^{+}\left(\mathrm{CH}_{2}\right)_{3} \mathrm{COOH}\left[\mathrm{MH}^{+}: 286.2 \mathrm{~m} / \mathrm{z}\right.\right.$, abundance $100 \%$; corresponding isotope peak at $287.2 \mathrm{~m} / \mathrm{z}$, abundance $17 \%$ ] and a byproduct peak due to the quaternary ammonium salt $\left(\mathrm{PyCH}_{2}\right)_{3} \mathrm{~N}^{+}\left(\mathrm{CH}_{2}\right)_{3} \mathrm{COOH}\left[\mathrm{M}^{+}: 377.2 \mathrm{~m} / z\right.$, abundance $43 \%$; corresponding isotope peak at $378.2 \mathrm{~m} / \mathrm{z}$, abundance 11\%]. All other peaks are lower than $10 \%$ (data not presented). Confirmation of structure is apparent in that fragmentation of the molecular ion peak 286.2 $\mathrm{m} / \mathrm{z}$ provide a series of fragment peaks: $\left(\mathrm{PyCH}_{2}\right)_{2} \mathrm{NH}^{+}\left(\mathrm{CH}_{2}\right)_{3} \mathrm{COOH}, \mathrm{m} / \mathrm{z} 286.2$, abundance 15.5\%; $\left(\mathrm{PyCH}_{2}\right)_{2} \mathrm{~N}\left(\mathrm{CH}_{2}\right)_{3} \mathrm{CO}^{+}, \mathrm{m} / z$ 268.2, abundance 25\%; $\left(\mathrm{PyCH}_{2}\right)_{2} \mathrm{NH}_{2}{ }^{+}, \mathrm{m} / z, 200.2$, abundance 13\%; $\mathrm{Py}-\mathrm{CH}=\mathrm{NH}^{+}\left(\mathrm{CH}_{2}\right)_{3} \mathrm{COOH} \mathrm{m} / z$ 193.1, 25.0\%; $\mathrm{Py}-\mathrm{CH}=\mathrm{N}\left(\mathrm{CH}_{2}\right)_{3} \mathrm{CO}^{+} \mathrm{m} / \mathrm{z}$ $175.1,16 \%$.

\section{Formation Kinetics of ${ }^{99 \mathrm{~m}} \mathrm{Tc}(\mathrm{CO})_{3}{ }^{+}-\mathrm{BPABA}$ vs ${ }^{99 \mathrm{~m}} \mathrm{Tc}(\mathrm{CO})_{3}{ }^{+-}$-Histidine}

On RP HPLC (System 2) the ${ }^{99} \mathrm{~m} \mathrm{Tc}(\mathrm{CO})_{3}{ }^{+}$core elutes at 4 min (Figure $2 \mathrm{~A}$ ) as described by the manufacturer and forms complexes with both BPABA and histidine (Figures $2 \mathrm{~B}$ and $2 \mathrm{C}$ ), resulting in single peaks and indicating a radiochemical purity of over $90 \%$. Reaction times over 5-40 min in boiling water makes no difference in complex formation as shown by HPLC profiles identical to that of Figure 2B or 2C (data not presented). However, heating more than 60 min considerably increases the impurity peaks with both ${ }^{99 \mathrm{~m}} \mathrm{Tc}(\mathrm{CO})_{3}{ }^{+}-\mathrm{BPABA}$ and ${ }^{99 \mathrm{~m}} \mathrm{Tc}$ $(\mathrm{CO})_{3}{ }^{+}$-histidine (data not presented). It was therefore judged safe in this study to employ a routine heating time of $20 \mathrm{~min}$ for complex formation.

\section{In Vitro Stability of ${ }^{99 \mathrm{~m}} \mathrm{Tc}(\mathrm{CO})_{3}{ }^{+-}-\mathrm{BPABA}$ vs ${ }^{99 \mathrm{~m}} \mathrm{Tc}(\mathrm{CO})_{3}{ }^{+-}$-Histidine}

Both ${ }^{99} \mathrm{~m} \mathrm{Tc}(\mathrm{CO})_{3}{ }^{+}-\mathrm{BPABA}$ and ${ }^{99} \mathrm{~m} \mathrm{Tc}(\mathrm{CO})_{3}{ }^{+}$-histidine are unaffected by $24 \mathrm{~h}$ incubation in $37^{\circ} \mathrm{C}$ saline, but both show serum protein binding after $24 \mathrm{~h}$ incubation in $37^{\circ} \mathrm{C}$ human serum (data not presented). The percentage of serum binding with ${ }^{99 \mathrm{~m}} \mathrm{Tc}(\mathrm{CO})_{3}{ }^{+}$-histidine is higher than that with ${ }^{99 \mathrm{~m}} \mathrm{Tc}(\mathrm{CO}){ }_{3}{ }^{+}-\mathrm{BPABA}\left(20 \mathrm{vs} 9.5 \%\right.$ at $24 \mathrm{~h}$ ), indicating that ${ }^{99 \mathrm{~m}} \mathrm{Tc}(\mathrm{CO}){ }_{3}{ }^{+}-$ histidine may be less stable against transchelation to proteins $\operatorname{than}^{99 \mathrm{~m}} \mathrm{Tc}(\mathrm{CO})_{3}{ }^{+}-\mathrm{BPABA}$ under these conditions.

Ligand exchange between BPABA and histidine was also investigated by SE HPLC (system 3). In this system, the ${ }^{99 \mathrm{~m}} \mathrm{Tc}(\mathrm{CO})_{3}{ }^{+}$core itself does not elute probably due to interaction of the core with the cross-linked agarose matrix. The HPLC chromatograms of ${ }^{99 \mathrm{~m}} \mathrm{Tc}(\mathrm{CO})_{3}{ }^{+}-$ histidine and ${ }^{99 \mathrm{~m}} \mathrm{Tc}(\mathrm{CO})_{3}{ }^{+}-\mathrm{BPABA}$ are shown in Figure $3 \mathrm{~A}$ and $3 \mathrm{D}$, respectively. Incubation of ${ }^{99 \mathrm{~m}} \mathrm{Tc}(\mathrm{CO})_{3}{ }^{+}$-histidine with a 5000 molar excess of BPABA pH 7 at $37{ }^{\circ} \mathrm{C}$ over $1 \mathrm{~d}$ shows minimal replacement of histidine by BPABA (Figure 3B); however, heating of the same mixture in a boiling water bath for $6 \mathrm{~h}$ induces almost total replacement of histidine by BPABA (Figure 3C). In contrast, incubation of ${ }^{99 \mathrm{~m}} \mathrm{Tc}(\mathrm{CO})_{3}{ }^{+}-\mathrm{BPABA}$ with a 5000 molar excess of histidine shows no replacement of BPABA (Figure 3E) even at $100{ }^{\circ} \mathrm{C}$ for $6 \mathrm{~h}$ (Figure 3F). The capability of BPABA to replace histidine in its ${ }^{99 \mathrm{~m}} \mathrm{Tc}(\mathrm{CO})_{3}{ }^{+}$complex, but not vice versa, reflect a higher affinity of BPABA for ${ }^{99 \mathrm{~m}} \mathrm{Tc}$ tricarbonyl. 


\section{Biodistribution and In Vivo Stability of ${ }^{99 \mathrm{~m}} \mathrm{Tc}(\mathrm{CO})_{3}{ }^{+}-\mathrm{BPABA}$ vs ${ }^{99 \mathrm{~m}} \mathrm{Tc}(\mathrm{CO})_{3}{ }^{+}-$Histidine}

Table 1 presents the biodistribution in normal mice at 35 min postadministration of ${ }^{99} \mathrm{~m} \mathrm{Tc}$ $(\mathrm{CO})_{3}{ }^{+}-\mathrm{BPABA}$ and ${ }^{99 \mathrm{~m}} \mathrm{Tc}(\mathrm{CO})_{3}{ }^{+}$-histidine. The biodistribution of ${ }^{99 \mathrm{~m}} \mathrm{Tc}(\mathrm{CO})_{3}{ }^{+}-\mathrm{BPABA}$ shows rapid hepatobiliary excretion with $57 \%$ in the small intestine, $5 \%$ in the large intestine, and $15 \%$ in liver including gall bladder at $35 \mathrm{~min}$. Less than $8 \%$ was excreted into urine at this time. By SE HPLC analysis, only $30 \%$ (2.4\%ID) of the radioactivity in urine was present as ${ }^{99 \mathrm{~m}} \mathrm{Tc}(\mathrm{CO})_{3}{ }^{+}-\mathrm{BPABA}$. The remaining urine radioactivity was due to the approximately $5 \%$ radiochemical impurities in the ${ }^{99 \mathrm{~m}} \mathrm{Tc}(\mathrm{CO})_{3}{ }^{+}-\mathrm{BPABA}$ injectate. While clearance of these impurities via the kidneys was rapid and quantitative, the excretion of ${ }^{99 \mathrm{~m}} \mathrm{Tc}(\mathrm{CO})_{3}{ }^{+}-\mathrm{BPABA}$ via the kidney was largely negligible. By contrast, ${ }^{99 \mathrm{~m}} \mathrm{Tc}(\mathrm{CO})_{3}{ }^{+}$-histidine is predominantly excreted through kidney as reported previously $(10,11)$ with $50 \%$ of ${ }^{99 \mathrm{~m}} \mathrm{Tc}(\mathrm{CO}){ }_{3}{ }^{+}-$histidine in urine in $35 \mathrm{~min}$. Though rapid, the kidney excretion is not as rapid as typical kidney imaging agents such as ${ }^{99 \mathrm{~m}} \mathrm{Tc}-\mathrm{BPHA}(18),{ }^{99 \mathrm{~m}} \mathrm{Tc}-\mathrm{DTPA}$ (19), and ${ }^{99 \mathrm{~m}} \mathrm{Tc}^{-\mathrm{MAG}_{3}}$ (20).

The in vivo stabilities of ${ }^{99 \mathrm{~m}} \mathrm{Tc}(\mathrm{CO})_{3}{ }^{+}$-BPABA and ${ }^{99} \mathrm{~m} \mathrm{Tc}(\mathrm{CO})_{3}{ }^{+}$-histidine were evaluated by comparing the SE HPLC radiochromatograms of the injectates with that of urine, plasma, and extracts of small intestine obtained from animals administered the complexes $35 \mathrm{~min}$ earlier. As shown in Figure $4,{ }^{99 \mathrm{~m}} \mathrm{Tc}(\mathrm{CO})_{3}{ }^{+}-\mathrm{BPABA}$ is still intact in plasma as well as in the wash from the small intestines. Because of the negligible urinary excretion of ${ }^{99 \mathrm{~m}} \mathrm{Tc}(\mathrm{CO})_{3}{ }^{+}$ BPABA (less than $8 \%$ ID) the HPLC profile of urine is not presented. Like ${ }^{99 \mathrm{~m}} \mathrm{Tc}(\mathrm{CO})_{3}{ }^{+}-$ BPABA, ${ }^{99 \mathrm{~m}} \mathrm{Tc}(\mathrm{CO})_{3}{ }^{+}$-histidine is also intact in plasma and in urine. Because of the negligible hepatobilliary excretion of ${ }^{99 \mathrm{~m}} \mathrm{Tc}(\mathrm{CO})_{3}{ }^{+}$-histidine, an HPLC profile of small intestine wash was not obtained in this case. These results show that both ${ }^{99 \mathrm{~m}} \mathrm{Tc}(\mathrm{CO})_{3}{ }^{+}-\mathrm{BPABA}$ and ${ }^{99 \mathrm{~m}} \mathrm{Tc}$ $(\mathrm{CO})_{3}{ }^{+}$-histidine are "stable" in vivo.

\section{DISCUSSION}

In this investigation, BPABA has been chosen as a model compound because of its ease of synthesis and the presence of a pendent carboxylate group for conjugation to biomolecules. In addition, the molecule was selected to avoid five- or six-membered chelation rings with the ${ }^{99 \mathrm{~m}}$ Tc tricarbonyl core. Thus free BPABA should exhibit similar labeling properties to conjugated BPABA and therefore should serve as a reliable model for the behavior of BPABAconjugated biomolecules. The result of this investigation show that the properties of complex formation and stability of BPABA are comparable, if not superior to, that of histidine, often considered a model compound for ${ }^{99 \mathrm{~m}} \mathrm{Tc}$ tricarbonyl labeling $(10,11,14)$.

Our interest in tricarbonyl labeling is in connection with phosphodiamidate morpholino (MORF) pretargeting in which it will eventually be necessary to radiolabel MORF with ${ }^{188} \mathrm{Re}$ and in a manner that avoids unacceptably large reoxidation to ${ }^{188} \mathrm{ReO}_{4}{ }^{-}$. Because of the recognized kinetic inertness of these complexes (6-8), tricarbony labeling of biomolecules via BPABA is expected to avoid the oxidation problem at least to a greater degree than experienced in this laboratory with a more conventional labeling method for ${ }^{188} \mathrm{Re}$ using $\mathrm{MAG}_{3}$ as a chelator (5). However, a drawback to the use of the tricarbonyl strategy resulting from kinetic inertness is "high" chelator concentration required for quantitative labeling $(10,11)$, a phenomenon verified in this research. A chelator concentration of $10^{-4}$ or $10^{-5} \mathrm{M}$ was required for a labeling efficiency of $90 \%$, even with histidine. By contrast, the concentration of $\mathrm{MAG}_{3}$ can be reduced to below $10^{-6} \mathrm{M}$ when labeling $\mathrm{MAG}_{3}$-conjugated MORF or phosphorothioate DNA while still achieving a labeling efficiency of over $90 \%(21)$.

Parenthetically, it may be worth mentioning that the results presented here on the properties of ${ }^{99 \mathrm{~m}} \mathrm{Tc}(\mathrm{CO})_{3}{ }^{-}$BPABA suggest that this complex may have utility for imaging the hepatobiliary system. The ${ }^{99 \mathrm{~m}} \mathrm{Tc}$-labeled hepatobiliary imaging agents include ${ }^{99 \mathrm{~m}} \mathrm{Tc}-\mathrm{IDAs}$ $(22,23),{ }^{99 \mathrm{~m} T c-p y r i d o x y l i d i n e ~ g l u t a m a t e ~(24), ~}{ }^{99 \mathrm{~m}} \mathrm{Tc}-$ penicillamine (25), and ${ }^{99 \mathrm{~m}} \mathrm{Tc}-\mathrm{MAG}_{3}-$ 
biocytin (26,27), with ${ }^{99} \mathrm{~m} \mathrm{Tc}-\mathrm{IDAs}$ being the most extensively investigated. Both ${ }^{99 \mathrm{~m}} \mathrm{Tc}-\mathrm{IDAs}$ and ${ }^{99 \mathrm{~m}} \mathrm{Tc}-\mathrm{MAG}_{3}$-biocytin are excreted exclusively via the hepatobiliary pathway in contrast to both ${ }^{99 \mathrm{~m}} \mathrm{Tc}$-pyriddoxylidine glutamate and ${ }^{99 \mathrm{~m}} \mathrm{Tc}$-penicillamine. Similar to the ${ }^{99 \mathrm{~m}} \mathrm{Tc}-$ IDAs ( $<97 \%$ ID) and ${ }^{99} \mathrm{~m} \mathrm{Tc}-\mathrm{MAG}_{3}-$ biocytin $(>90 \% \mathrm{ID}),{ }^{99 \mathrm{~m}} \mathrm{Tc}(\mathrm{CO})_{3}-\mathrm{BPABA}$ is also cleared exclusively via the hepatobiliary pathway (97\%ID).

The mechanism of hepatobiliary processing is reported to be different among these agents. As shown in Figure 5, the structures of the ${ }^{99 \mathrm{~m}} \mathrm{Tc}-\mathrm{IDAs}$, ${ }^{99 \mathrm{~m}} \mathrm{Tc}-\mathrm{MAG}_{3}$-biocytin and ${ }^{99 \mathrm{~m}} \mathrm{Tc}$ $(\mathrm{CO})_{3}-\mathrm{BPABA}$ are fundamentally different and, as a result, each is expected to clear by a different mechanisms of hepatobiliary excretion. For example, ${ }^{99 \mathrm{~m}} \mathrm{Tc}-\mathrm{IDAs}$ and ${ }^{99 \mathrm{~m}} \mathrm{Tc}-$ $\mathrm{MAG}_{3}$-biocytin must clear by different mechanisms since only the former can be blocked by endogenous bilirubin (26) with the result that hepatobiliary function in patients with high serum

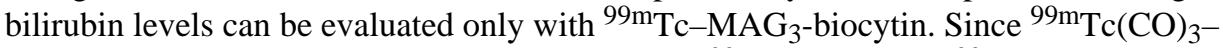
BPABA possesses a different structure to those of ${ }^{99} \mathrm{~m} \mathrm{Tc}-\mathrm{IDAs}$ and ${ }^{99 \mathrm{~m}} \mathrm{Tc}-\mathrm{MAG}_{3}$-biocytin, the mechanism by which ${ }^{99 \mathrm{~m}} \mathrm{Tc}(\mathrm{CO})_{3}$-BPABA clears through the liver may be different as well. Therefore, should ${ }^{99} \mathrm{~m} \mathrm{Tc}(\mathrm{CO})_{3}-\mathrm{BPABA}$ be investigated as a potential imaging agent for the hepatobiliary system, it may be shown to be cleared via a unique transporter, the function of which could then be evaluated.

\section{CONCLUSION}

The tridentate chelator $N, N$-bis(2-pyridylmethyl)-4-aminobutyric acid (BPABA) is easily synthesized and forms a "stable" complex with ${ }^{99 \mathrm{~m}} \mathrm{Tc}(\mathrm{CO})_{3}{ }^{+}$. The property of stability might apply to radiorhenium as well for use in radiotherapy studies. Further development efforts are needed to improve the labeling recipes for high specific activity. Finally, the ${ }^{99 \mathrm{~m}} \mathrm{Tc}(\mathrm{CO})_{3}-$ BPABA complex itself is hepatobiliary specific and might be useful in imaging malfunction of specific transporter in liver.

\section{Acknowledgements}

The authors are grateful to Mary Dyszlewski (Mallinckrodt Medical, St. Louis, MO) for providing the technetium tricarbonyl kits. Financial support for this investigation was provided in part by the National Institutes of Health (CA94994, CA107360, and CA79507).

\section{References}

1. Liu G, Mangera K, Liu N, Gupta S, Rusckowski M, Hnatowich DJ. Tumor pretargeting in mice using technetium-99m labeled morpholinos, a DNA analogue. J Nucl Med 2002;43:384-391. [PubMed: 11884499]

2. Liu G, Zhang S, He J, Liu N, Gupta S, Rusckowski M, Hnatowich DJ. The Influence of Chain Length and Base Sequence on the Pharmacokinetic behavior of ${ }^{99 \mathrm{~m}} \mathrm{Tc}-$ Morpholinos in Mice. Q J Nucl Med 2002;46:233-243. [PubMed: 12134139]

3. Liu G, Liu C, Zhang S, He J, Liu N, Gupta S, Rusckowski M, Hnatowich DJ. Investigations of Technetium-99m Morpholino Pretargeting in Mice. Nucl Med Commun 2003;24:697-705. [PubMed: 12766607]

4. Liu G, He J, Dou S, Gupta S, Vanderheyden JL, Rusckowski M, Hnatowich DJ. Pretargeting in tumored mice with radiolabeled morpholino oligomer showing low kidney uptake. Eur J Nucl Med Mol Imaging 2004;31:417-424. [PubMed: 14691611]

5. Liu CB, Liu GZ, Liu N, Zhang YM, He J, Rusckowski M, Hnatowich DJ. Radiolabeling morpholinos with ${ }^{90} \mathrm{Y},{ }^{111} \mathrm{In},{ }^{188} \mathrm{Re}$ and ${ }^{99 \mathrm{~m}} \mathrm{Tc}$. Nucl Med Biol 2003;30:141-149. [PubMed: 12623113]

6. Alberto R. $\left[\mathrm{Tc}(\mathrm{CO})_{3}\right]^{+}$chemistry: a promising new concept for SPET? For. Eur J Nucl Med Mol Imaging 2003;30:1299-1302. [PubMed: 12898204]

7. Welch MJ, Lewis JS. $\left[\mathrm{Tc}(\mathrm{CO})_{3}\right]^{+}$chemistry: a promising new concept for SPECT? Against. Eur J Nucl Med Mol Imaging 2003;30:1302-1304. [PubMed: 12898205] 
8. Ballinger JR, Cooper MS, Mather SJ. Re: Controversies- $\left[\mathrm{Tc}(\mathrm{CO})_{3}\right]^{+}$chemistry: a promising new concept for SPET? Eur J Nucl Med Mol Imaging 2004;31:304-305. [PubMed: 15129716](letter)

9. He J, Liu CB, Vanderheyden JL, Liu G, Dou S, Rusckowski M, Hnatowich DJ. Radiolabeling morpholinos with ${ }^{188}$ Re tricarbonyl provides improved in vitro and in vivo stability to reoxidation. Nucl Med Commun 2004;25:731-736. [PubMed: 15208502]

10. Egli A, Alberto R, Tannahill L, Schibli R, Abram U, Schaffland A, Waibel R, Tourwe D, Jeannin L, Iterbeke K, Schubiger PA. Organometallic ${ }^{99} \mathrm{~m}$ Tc-aquaion labels peptide to an unprecedented high specific activity. J Nucl Med 1999;40:1913-1917. [PubMed: 10565789]

11. Schibli R, La Bella R, Alberto R, Garcia-Garayoa E, Ortner K, Abram U, Schubiger PA. Influence of the denticity of ligand systems on the in vitro and in vivo behavior of ${ }^{99 \mathrm{~m}} \mathrm{Tc}(\mathrm{I})$-tricarbonyl complexes: a hint for the future functionalization of biomolecules. Bioconjugate Chem 2000;11:345351.

12. Alberto R, Schibli R, Egli A, Schubiger AP. A novel organometallic aqua complex of technetium for

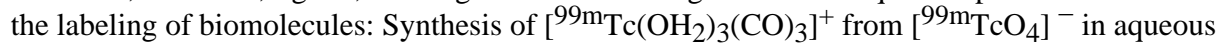
solution and its reaction with a bifunctional ligand. J Am Chem Soc 1998;120:7987-7988.

13. Stichelberger A, Waibel R, Dumas C, Schubiger PA, Schibli R. Versatile synthetic approach to new bifunctional chelating agents tailor-made for labeling with the fac- $\left[\mathrm{M}(\mathrm{CO})_{3}\right]^{+}$core $\left(\mathrm{M}=\mathrm{Tc},{ }^{99 \mathrm{~m}} \mathrm{Tc}\right.$, $\mathrm{Re})$ : synthesis, in vitro, and in vivo behavior of the model complex $\left[\mathrm{M}(\mathrm{APPA})(\mathrm{CO})_{3}\right](\mathrm{APPA}=[(5-$ amino-pentyl)-pyridin-2-yl-methyl-amino]-acetic acid). Nucl Med Biol 2003;30:465-470. [PubMed: 12831983]

14. Pak JK, Benny P, Spingler B, Ortner K, Alberto R. functionalization of metal and organic protected 1-histidine for a highly efficient, direct labeling of biomolecules with $\left[\mathrm{Tc}\left(\mathrm{OH}_{2}\right)_{3}(\mathrm{CO})_{3}\right]^{+}$Chemistry 2003 Nepsilon;9:2053-2061. [PubMed: 12740853]

15. Kramer DJ, Davison A, Davis WM, Jones AG. N-(2-Mercaptoethyl)picolylamine as a diaminomonothiolate ligand for the "fac-[Re(CO) $\left.)_{3}\right]^{+"}$ core. Inorg Chem 2002;41:6181-6183. [PubMed: 12444754]

16. Pietzsch HJ, Gupta A, Reisgys M, Drews A, Seifert S, Syhre R, Spies H, Alberto R, Abram U, Schubiger PA, Johannsen B. Chemical and biological characterization of technetium(I) and rhenium (I) tricarbonyl complexes with dithioether ligands serving as linkers for coupling the $\mathrm{Tc}(\mathrm{CO})_{3}$ and $\operatorname{Re}(\mathrm{CO})_{3}$ moieties to biologically active molecules. Bioconjugate Chem 2000;11:414-424.

17. Banerjee SR, Levadala MK, Lazarova N, Wei L, Valliant JF, Stephenson KA, Babich JW, Maresca $\mathrm{KP}$, Zubieta J. Bifunctional single amino acid chelates for labeling of biomolecules with the [Tc(CO) $\left.{ }_{3}\right]^{+}$and $\left[\mathrm{Re}(\mathrm{CO})_{3}\right]^{+}$cores. Crystal and molecular structures of $\left[\operatorname{ReBr}(\mathrm{CO})_{3}-\left(\mathrm{H}_{2} \mathrm{NCH}_{2} \mathrm{C}_{5} \mathrm{H}_{4} \mathrm{~N}\right)\right],[\operatorname{Re}$ $\left.(\mathrm{CO})_{3}\left[\left(\mathrm{C}_{5} \mathrm{H}_{4} \mathrm{NCH}_{2}\right)_{2} \mathrm{NH}\right]\right] \mathrm{Br},\left[\mathrm{Re}(\mathrm{CO})_{3}-\left[\left(\mathrm{C}_{5} \mathrm{H}_{4} \mathrm{NCH}_{2}\right)_{2} \mathrm{NCH}_{2} \mathrm{CO}_{2} \mathrm{H}\right]\right] \mathrm{Br},\left[\mathrm{Re}(\mathrm{CO})_{3}[\mathrm{X}(\mathrm{Y})\right.$ $\left.\left.\mathrm{NCH}_{2} \mathrm{CO}_{2} \mathrm{CH}_{2} \mathrm{CH}_{3}\right]\right] \mathrm{Br}(\mathrm{X}=\mathrm{Y}=2$-pyridylmethyl; $\mathrm{X}=2$-pyridylmethyl, $\mathrm{Y}=2$ - $(1-$ methylimidazolyl)methyl; $\mathrm{X}=\mathrm{Y}=2$-(1-methylimidazolyl)methyl), $\left[\operatorname{ReBr}(\mathrm{CO})_{3}\left[\left(\mathrm{C}_{5} \mathrm{H}_{4} \mathrm{NCH}_{2}\right) \mathrm{NH}\right.\right.$ $\left.\left.\left(\mathrm{CH}_{2} \mathrm{C}_{4} \mathrm{H}_{3} \mathrm{~S}\right)\right]\right]$, and $\left[\mathrm{Re}(\mathrm{CO})_{3}\left[\left(\mathrm{C}_{5} \mathrm{H}_{4} \mathrm{NCH}_{2}\right) \mathrm{N}\left(\mathrm{CH}_{2} \mathrm{C}_{4} \mathrm{H}_{3} \mathrm{~S}\right)\left(\mathrm{CH}_{2} \mathrm{CO}_{2}\right)\right]\right]$. Inorg Chem 2002;41:6417-6425. [PubMed: 12444786]

18. Liu G, Zhang C, Liu F, Wang R, Fu Z, Li G, Miao Z. ${ }^{99 m}$ Tc-N,N'-bis(aminoethyl)propanediamine hexaacetic acid (BPHA): a glomerular filtration agent similar to ${ }^{99 \mathrm{~m}} \mathrm{Tc}-\mathrm{DTPA}$. Nucl Med Biol 2002;29:399-404. [PubMed: 12031874]

19. Liu GZ, Liu F, Yang T, Miao ZX, Fang JD. Structural consideration of divalent ion complexes of BPHA for fast renal excretion of ${ }^{99 m}$ Tc-BPHA. J. Labelled Compd, Radiopharm 2000;43:493-503.

20. Fritzberg AR, Kasina S, Eshima D, Johnson DL. Synthesis and biological evaluation of technetium-99m MAG $_{3}$ as a hippuran replacement. J Nucl Med 1986;27:111- 116. [PubMed: 2934521]

21. Liu G, Zhang S, He J, Zhu Z, Rusckowski Z, Hnatowich DJ. Improving the Labeling of S-Acetyl NHS-MAG 3 -Conjugated Morpholino Oligomers. Bioconjugate Chem 2002;13:893-897.

22. Nunn AD, Loberg MD, Conley RA. A structure-distribution-relationship approach leading to the development of Tc-99m mebrofenin: an improved cholescintigraphic agent. J Nucl Med 1983;24:423-430. [PubMed: 6842291]

23. Krishnamurthy S, Krishnamurthy GT. Technetium-99m-iminodiacetic acid organic anions: review of bio-kinetics and clinical application in hepatology. Hepatology 1989;9:139-153. [PubMed: 2642291] 
24. Baker RJ, Bellen JC, Ronai PM. Technetium-99m-pyridoxylideneglutamate: a new hepatobiliary radio-pharmaceutical. I. Experimental aspects. J Nucl Med 1975;16:720-727. [PubMed: 240915]

25. Tubis M, Krishnamurthy GT, Endow JS, Blahd WH. ${ }^{99} \mathrm{~m}$ Tc-penicillamine, a new cholescintigraphic agent. J Nucl Med 1972;13:652-654. [PubMed: 5041645]

26. Kim M, Seidel J, Le N, Kim IS, Yoo TM, Barker C, Kobayashi H, Green MV, Carrasquillo JA, Paik $\mathrm{CH}$. Evaluation of ${ }^{99 \mathrm{~m}} \mathrm{Tc}$-mercaptoacetyltriglycine-biocytin as a new hepatobiliary imaging agent in mice co-injected with bilirubin. Nucl Med Biol 1999;26:43-49. [PubMed: 10096500]

27. Jeong JM, Kinuya S, Paik CH, Saga T, Sood VK, Neumann RC, Reynolds JC, Carrasquillo JA. Synthesis of a Tc-99m $\mathrm{MAG}_{3}$-biotin conjugate as a biliary agent. J Labelled Compd Radiopharm 1993;32:88-89. 
Aromatic $\mathrm{N}$-heterocycle-amine-carboxylate
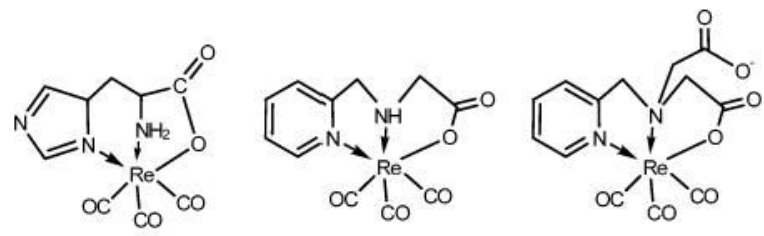

Aromatic N-heterocycle-amine-thiol
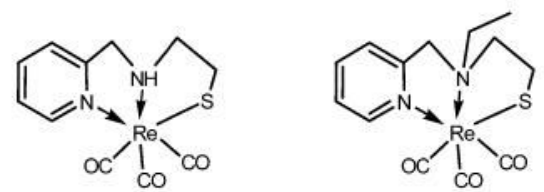

Thioether-thioether-carboxylate
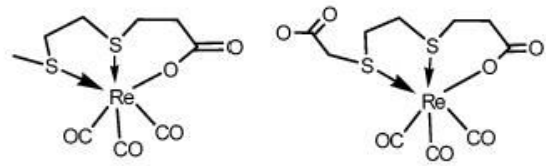

Aromatic $\mathrm{N}$-heterocycle-amine-aromatic $\mathrm{N}$-heterocycle
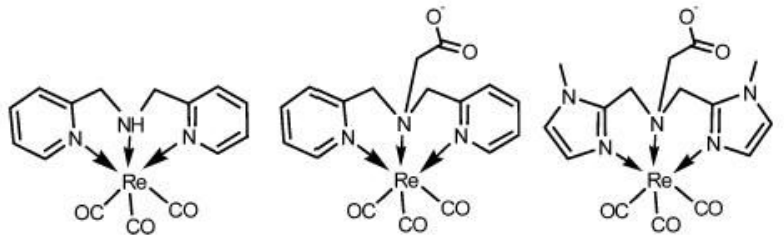

Figure 1.

Examples of chemical structures between Re tri-carbonyl and tridentates of different classes. 


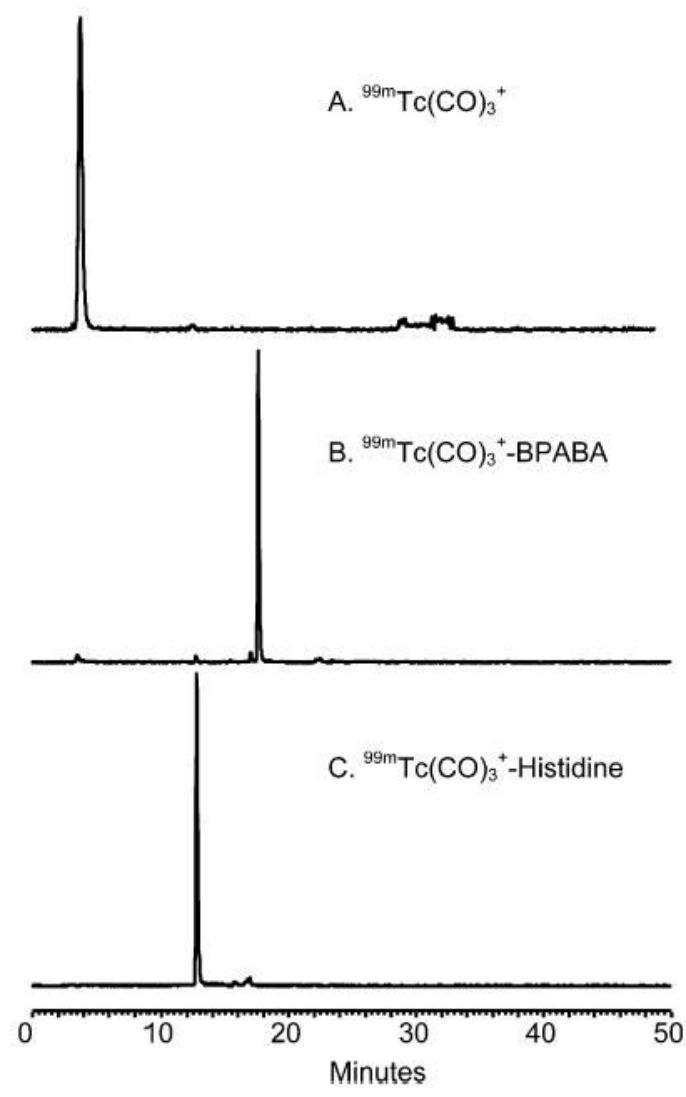

Figure 2.

Radiochromatograms by RP HPLC (System 2) of ${ }^{99 \mathrm{~m}} \mathrm{Tc}(\mathrm{CO})_{3}{ }^{+}$core (panel A) and ${ }^{99 \mathrm{~m}} \mathrm{Tc}$ $(\mathrm{CO})_{3}{ }^{+}-\mathrm{BPABA}$ and ${ }^{99 \mathrm{~m}} \mathrm{Tc}(\mathrm{CO})_{3}{ }^{+}$-histidine following incubation at $37{ }^{\circ} \mathrm{C}$ for $40 \mathrm{~min}$ or less (panels $\mathrm{B}$ and $\mathrm{C}$, respectively). 


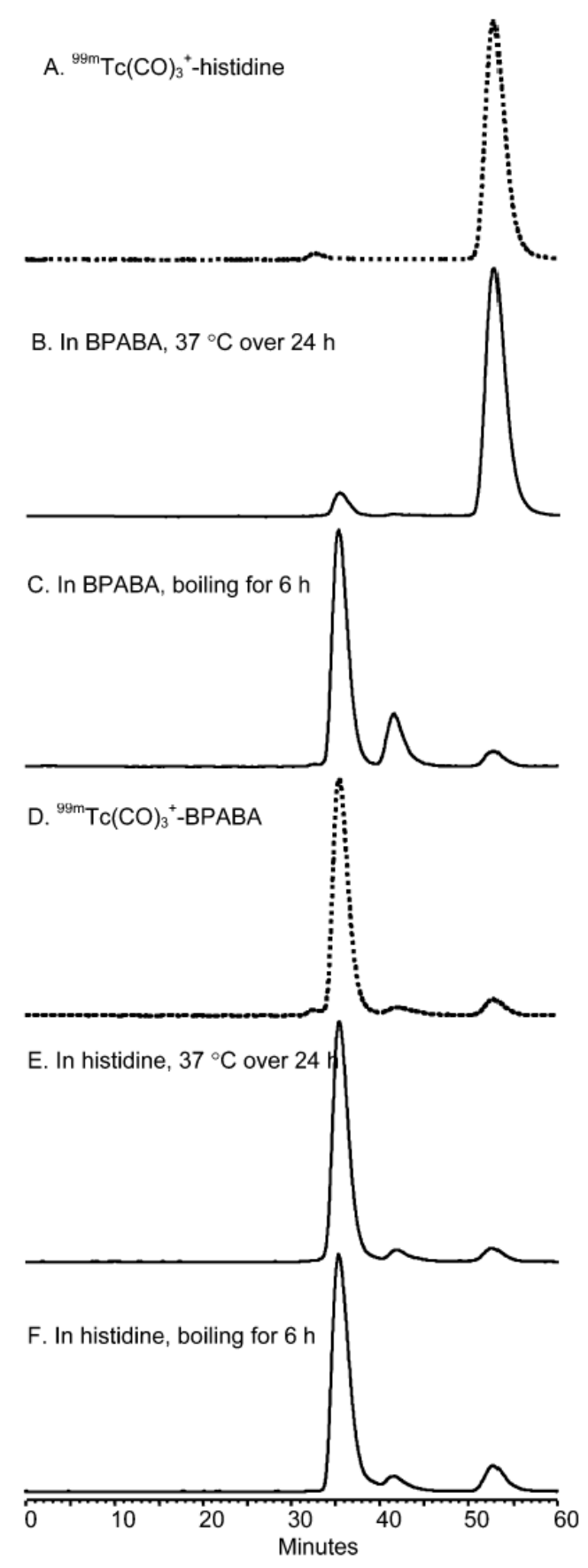

Figure 3.

Radiochromatograms by SE HPLC (System 3) of ${ }^{99}{ }^{9} \mathrm{Tc}(\mathrm{CO}){ }_{3}{ }^{+}$-histidine alone (panels A) and after incubation with a 5000-fold molar excess of BPABA for $24 \mathrm{~h}$ at $37^{\circ} \mathrm{C}$ (panel B) and $6 \mathrm{~h}$ at $100{ }^{\circ} \mathrm{C}($ Panel $\mathrm{C})$. Also presented are radiochromatograms of ${ }^{99} \mathrm{~m} \mathrm{Tc}(\mathrm{CO})_{3}{ }^{+}-\mathrm{BPABA}$ alone (panels D) and after incubation with a 5000-fold molar excess of histidine for $24 \mathrm{~h}$ at $37^{\circ} \mathrm{C}$ (panel E) and $6 \mathrm{~h}$ at $100{ }^{\circ} \mathrm{C}($ Panel F). 
${ }^{99 \mathrm{~m}} \mathrm{Tc}(\mathrm{CO}){ }_{3}$-BPABA

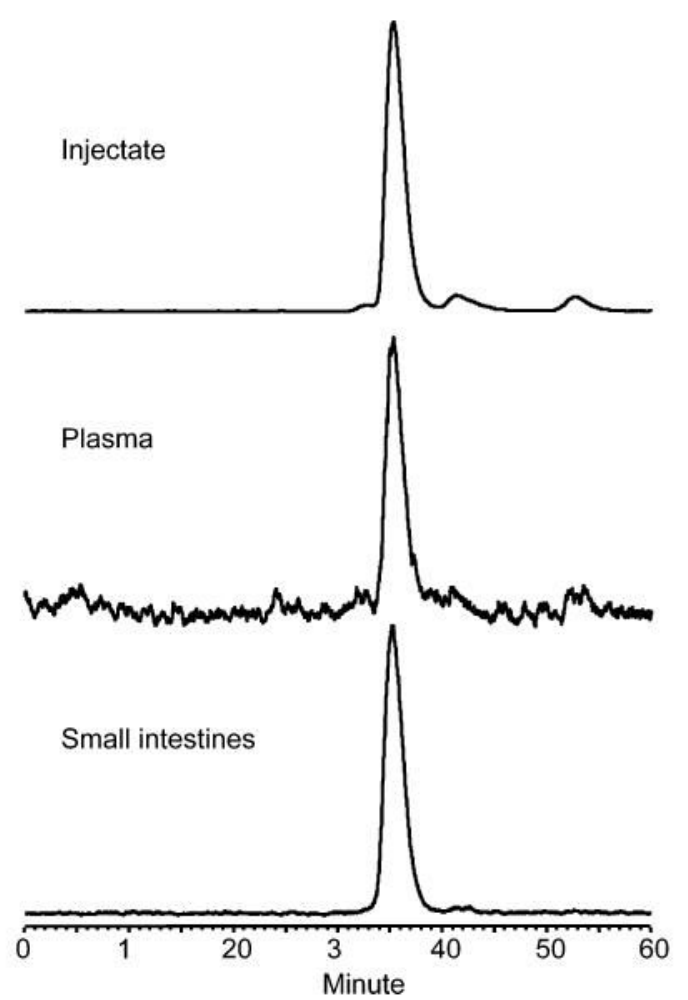

${ }^{99 \mathrm{~m}} \mathrm{Tc}(\mathrm{CO}){ }_{3}$-Histidine

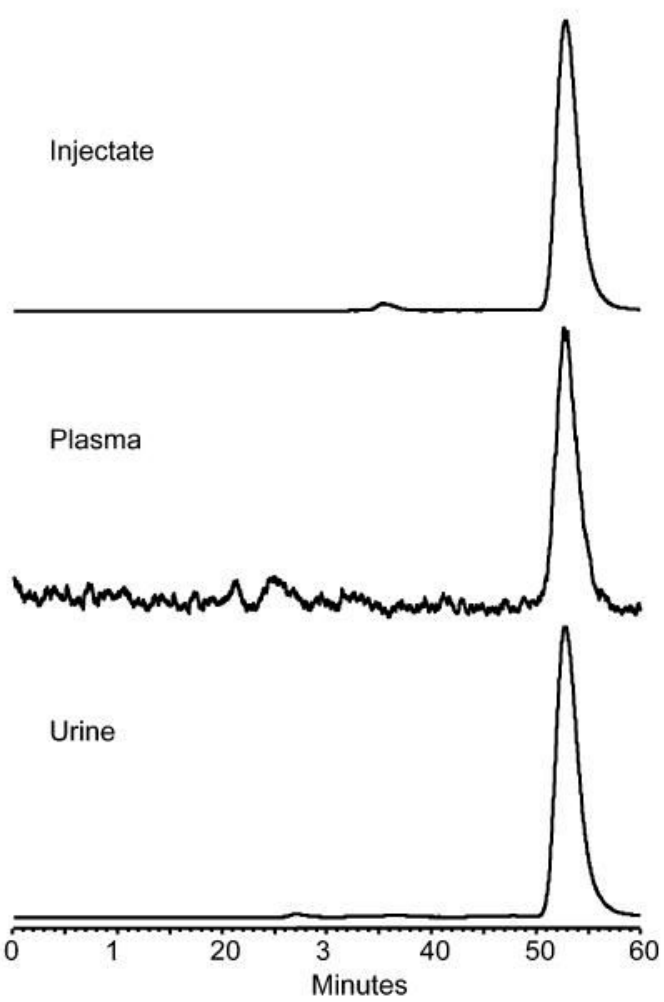

Figure 4.

Radiochromatograms by SE HPLC (System 3) of ${ }^{99 \mathrm{~m}} \mathrm{Tc}(\mathrm{CO})_{3}{ }^{+}-\mathrm{BPABA}$ injectate (top left panel) and ${ }^{99} \mathrm{~m} \mathrm{Tc}(\mathrm{CO})_{3}{ }^{+}$-histidine injectate (top right panel) and analysis of plasma (middle row), extract from the small intestines (in the case of $\left.{ }^{99} \mathrm{~m} \mathrm{Tc}(\mathrm{CO})_{3}{ }^{+}-\mathrm{BPABA}\right)$ (left bottom panel), and urine (in the case of ${ }^{99} \mathrm{~m} \mathrm{Tc}(\mathrm{CO})_{3}{ }^{+}$-hisidine) (right bottom panel) from an animal injected 35 min earlier. 


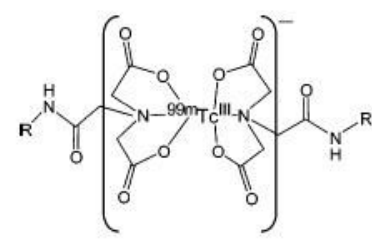

A

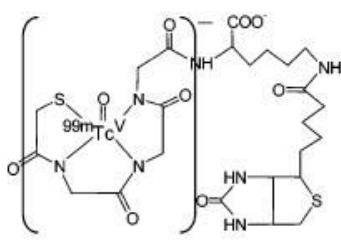

B

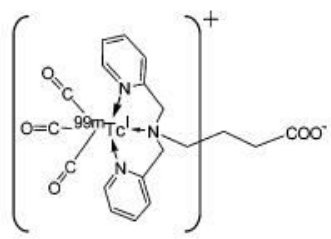

C

Figure 5.

Structures of reported hepatobiliary specific imaging agents. (A) ${ }^{99 \mathrm{~m}} \mathrm{Tc}-\mathrm{IDAs}$, (B) ${ }^{99 \mathrm{~m}} \mathrm{Tc}-$ $\mathrm{MAG}_{3}$-biocytin, and $(\mathrm{C})^{99 \mathrm{~m}} \mathrm{Tc}(\mathrm{CO})_{3}{ }^{+}$-BPABA. 
Table 1

Biodistribution in Normal Mice of ${ }^{99} \mathrm{~m} \mathrm{Tc}(\mathrm{CO})_{3}{ }^{+}-\mathrm{BPABA}$ and ${ }^{99 \mathrm{~m}} \mathrm{Tc}(\mathrm{CO})_{3}{ }^{+}-$Histidine at $35 \mathrm{~min}^{a}$

\begin{tabular}{|c|c|c|c|c|}
\hline \multirow[b]{2}{*}{ organ } & \multicolumn{2}{|c|}{ BPABA } & \multicolumn{2}{|c|}{ histidine } \\
\hline & mean & SD & mean & SD \\
\hline \multicolumn{5}{|c|}{ (a) $\% \mathrm{ID} / \mathrm{g}$} \\
\hline liver & 8.72 & 2.38 & 2.77 & 0.27 \\
\hline heart & 0.29 & 0.08 & 0.69 & 0.07 \\
\hline kidneys & 4.27 & 1.72 & 6.65 & 1.32 \\
\hline lungs & 0.55 & 0.10 & 1.94 & 0.11 \\
\hline spleen & 0.40 & 0.15 & 0.83 & 0.12 \\
\hline muscle & 0.13 & 0.05 & 0.38 & 0.02 \\
\hline blood & 0.73 & $\begin{array}{l}0.16 \\
\text { (b) } \% \text { ID/organ }\end{array}$ & 1.54 & 0.16 \\
\hline liver & 14.95 & 3.23 & 5.49 & 1.05 \\
\hline heart & 0.05 & 0.01 & 0.14 & 0.03 \\
\hline kidneys & 2.78 & 1.11 & 5.27 & 1.25 \\
\hline lungs & 0.12 & 0.02 & 0.43 & 0.04 \\
\hline spleen & 0.04 & 0.01 & 0.09 & 0.03 \\
\hline stomach & 1.08 & 0.15 & 0.65 & 0.12 \\
\hline sm. intestines & 57.35 & 8.78 & 3.35 & 0.28 \\
\hline lg. intestines & 5.14 & 1.19 & 0.57 & 0.07 \\
\hline muscle & 1.83 & 0.64 & 6.90 & 0.63 \\
\hline blood & 1.87 & 0.29 & 4.85 & 0.74 \\
\hline whole body & 92.5 & 1.7 & 50.6 & 4.0 \\
\hline
\end{tabular}

${ }^{a}$ Mean of $\% \mathrm{ID}$ or $\% \mathrm{ID} / \mathrm{g}$ with standard deviation (SD), $n=4$. 